\title{
Surveillance and molecular epidemiology of avian influenza viruses from birds in zoos, backyard flocks and live bird markets in Korea
}

\author{
Jin-Wook Jang ${ }^{1}$, Il-Hwan Kim ${ }^{1}$, Hyuk-Joon Kwon ${ }^{1}$, Seung-Min Hong ${ }^{1}$, Jae-Hong Kim ${ }^{1,2, *}$ \\ ${ }^{1}$ Laboratory of Avian Diseases, and ${ }^{2}$ Reseach Institute for Veterinary Science, College of Veterinary Medicine and \\ BK21 for Veterinary Science, Seoul National University, Seoul 151-742, Korea \\ (Received: October 12, 2012; Accepted: October 25, 2012)
}

\begin{abstract}
The circulation and infection of avian influenza virus (AIV) in zoos and backyard flocks has not been systematically investigated. In the present study, we surveyed the birds including those in live bird markets (LBMs) and evaluated co-circulation of AIVs among them. Overall, 26 H9N2 AIVs and one H6N2 AIV were isolated from backyard flocks and LBMs, but no AIVs were isolated from zoo birds. Genetic analysis of the HA and NA genes indicated that most of the H9N2 AIVs showed higher similarities to AIVs circulating in domestic poultry than to those in wild birds, while the H6N2 AIV isolate from an LBM did to AIVs circulating in migratory wild birds. In serological tests, $15 \%$ (391/2619) of the collected sera tested positive for AIVs by competitive-ELISA. Among them, $34 \%(131 / 391)$ of the sera tested positive for AIV H9 antigen by HI test, but only one zoo sample was H9 positive. Although AIVs were not isolated from zoo birds, the serological results indicated that infection of AIVs might occur in zoos. It was also confirmed that H9N2 AIVs continue to circulate and evolve between backyard flocks and LBMs. Therefore, continuous surveillance and monitoring of these flocks should be conducted to control further epidemics.
\end{abstract}

Keywords : avian influenza virus, backyard flock, zoo

\section{Introduction}

Avian influenza virus (AIV) is an eight segmented, negative-sense RNA virus that can infect various bird species. Infection of domestic poultry with AIVs typically produces syndromes ranging from asymptomatic infection to respiratory disease and decreased egg production to severe, systemic disease with almost $100 \%$ mortality.

AIVs have continued to be isolated from live bird markets (LBMs) worldwide, especially in Southeast Asia, China and Hong Kong [4, 7-10, 16, 26]. H9N2 AIVs belonging to two lineages represented by $\mathrm{A} / \mathrm{Qa} / \mathrm{HK} / \mathrm{G} 1 / 97$ and $\mathrm{A} / \mathrm{Dk} / \mathrm{HK} / \mathrm{Y} 280 /$ 97 are widespread in LBMs in China [9], and since 1994, the H7N2 low pathogenicity AIV (LPAIV) has been isolated from LBMs in New York [26]. Moreover, $60 \%$ of the LBMs in New York and New Jersey harbored an H7 LPAIV in 2001 $[4,7]$.

AIVs have also been isolated from zoos and backyard flocks. In Germany, highly pathogenic avian influenza virus (HPAIV) H5N1 was detected in wild birds, black swans kept in a zoo and backyard mixed duck and goose populations from 2006 to 2007 [22] Additionally, a surveillance program in Italy isolated H5 and H7 LPAIVs from backyard birds and wild birds between 1997 and 2003. Backyard birds have increased the risk of transmission of AIVs [24]. Backyard ducks in China and Hong Kong played an important role in spreading and transmitting AIVs between home-raised poultry and wild birds [28].

In Korea, the surveillance and characterization of AIVs circulating between LBMs and domestic poultry farms have been conducted and described, but AIV infections in zoos and backyard birds have not yet been investigated. In the present study, we surveyed the prevalence of AIVs in zoo and backyard birds and evaluated the risk of the spread and mutation of these AIVs. In addition, we compared AIV isolates from zoos, backyard farms and LBMs to determine the molecular epidemiological relationship among them.

\section{Materials and Methods}

\section{Sampling}

A total of 326 cloacal swabs and 326 serum samples from poultry from five zoos and 2243 cloacal swabs and 2,243 serum samples from backyard flocks concentrated in the 14 areas managed for national avian influenza surveillance, as well as 131 cecal tonsil and fecal samples and 50 serum samples from LBMs were collected from March 2010 to November 2011.

*Corresponding author

Tel: +82-2-880-1288, Fax: +82-2-880-1233

E-mail: kimhong@snu.ac.kr 


\section{Virus isolation and subtyping}

The supernatants from samples suspended in phosphate buffered saline (PBS) containing antibiotics were inoculated into 10-day-old specific pathogen free (SPF) embryonated chicken eggs and incubated at $37^{\circ} \mathrm{C}$ for $72 \mathrm{~h}$. Allantoic fluid was harvested and tested using the hemagglutination (HA) test. The subtype of each isolate was determined by RT-PCR using specific primers for the HA and Neuraminidase (NA) genes following the method described previously [6, 17].

\section{Genetic and phylogenetic analysis}

Viral RNA was extracted from the allantoic fluid of inoculated SPF eggs using a Viral Gen-spin kit (iNtRON Biotechnology, Korea) according to the manufacturer's instructions. The viral RNA was reverse transcribed using RT\&Go Mastermix (MP Biomedicals, USA) to generate cDNA following the manufacturer's instructions. PCR was performed as described previously using specific primers [12] and Ex Taq DNA polymerase (TaKaRa Bio, Japan) following the manufacturer's instructions. Amplified DNA fragments were extracted and purified using a QIAquick gel extraction kit (Qiagen, Germany), and the PCR products were sequenced at Cosmo GenTech (Korea) using an ABI 3730XL DNA sequencer (Applied Biosystems, USA). The sequences of isolated viruses were aligned and edited using BioEdit 7 software [11]. Phylogenetic trees were generated by the neighborjoining method using the MEGA 5.03 software [23] with 1000 bootstrap replications.

Six AIVs were selected based on the source, species, subtype and season that the AIVs were isolated (Table 1). Complete gene sequences of the eight segments of the six selected viruses were compared with previous Korean wild-bird and domestic H6 and H9 AIVs. AIVs from East-Asia were also included in the phylogenetic tree.

\section{Antigenic determination}

Receptor-destroying enzyme (RDE) was used to treat sera to eliminate non-specific serum inhibitors; treated sera were then tested with a competitive-ELISA (c-ELISA) kit (Bionote, Korea) following the manufacturer's instructions to detect all AIV subtype antibodies. Positive samples detected by c-ELISA were re-examined by hemagglutination inhibition (HI) tests using $\mathrm{H} 5, \mathrm{H} 7$ and $\mathrm{H} 9$ antigens to avoid false positive reactions and to confirm the AIV infection.

\section{Pathogenicity in chicken and mice}

Five 5-week-old SPF white leghorn layers and eight 4week-old female BALB/c mice were used to measure the pathogenicity of the six selected AIVs isolated from LBMs and backyard flocks. Animals were inoculated intranasally with $10^{5.5}-10^{6.0} \mathrm{EID}_{50}$ of each isolate. Tracheas and cecal tonsils were collected from the chickens at 5 days post inoculation (d.p.i.), and lungs were collected from the mice at 3 d.p.i.. Tissues were homogenized and inoculated into 10-dayold SPF embryonated eggs to determine the $\mathrm{EID}_{50}$. The body weight of the inoculated mice was measured on days 0 through 14 d.p.i..

\section{Results}

\section{Virus isolation and subtyping}

Out of 2700 samples, two H9N2 AIVs were isolated from backyard flocks and 24 H9N2 AIVs and one H6N2 AIV were from LBMs. To analyze the molecular epidemiological relationship between the AIVs isolated in backyard flocks and LBMs, five H9N2 AIVs including two isolates from backyard flocks and one H6N2 AIV were selected and sequenced for genetic characterization.

\section{Phylogenetic analysis of $\mathrm{H} 9 \mathrm{~N} 2$ viruses}

Although 26 H9N2 AIVs were isolated among the various bird species, the HA genes of all of the H9N2 isolates were clustered into the same lineage of H9N2 AIVs circulating in Korea (Fig. 1A), showing 97.7 100\% nucleotide identity. The NA genes of H9N2 isolates were divided into two different lineages, with the majority of the $\mathrm{N} 2$ genes being phylogenetically related to the $\mathrm{H} 9 \mathrm{~N} 2 \mathrm{AIVs}$ circulating among domestic farms and showing 98.0 100\% nucleotide identity. Only one H9N2 isolate from a backyard flock $(\mathrm{A} / \mathrm{Ck} / \mathrm{Kr} /$ $\mathrm{BC} 96 / 10)$ was clustered with the A/Dk/Kr/LPM17/05-like Korean H3N2 AIVs [21] (Fig. 1B).

The PB2 genes of the H9N2 isolates, except for $\mathrm{A} / \mathrm{Ck} / \mathrm{Kr} /$ BC96/10, were clustered in Group B including an HPAIV from a migratory wild bird in Korea. A/Ck/Kr/BC96/10 was similar to the $\mathrm{A} / \mathrm{Ck} / \mathrm{Kr} / 04116 / 04-l i k e$ Korean domestic chicken H9N2 lineage [19] (Fig. 1C). The PB1 and PA genes were

Table 1. Avian influenza virus isolates used in this study

\begin{tabular}{llll}
\hline \multicolumn{1}{c}{ Virus } & Subtypes & \multicolumn{1}{c}{ Species } & Sources \\
\hline $\mathrm{A} / \mathrm{Ck} / \mathrm{Kr} / \mathrm{L} 22 / 2010$ & H9N2 & Korean native chicken & Live bird market \\
$\mathrm{A} / \mathrm{Mallard} / \mathrm{Kr} / \mathrm{L} 30 / 2010$ & $\mathrm{H} 6 \mathrm{~N} 2$ & Aquatic bird & Live bird market \\
$\mathrm{A} / \mathrm{Ck} / \mathrm{Kr} / \mathrm{L} 65 / 2011$ & $\mathrm{H} 9 \mathrm{~N} 2$ & Korean native chicken & Live bird market \\
$\mathrm{A} / \mathrm{Dk} / \mathrm{Kr} / \mathrm{L} 83 / 2011$ & $\mathrm{H} 9 \mathrm{~N} 2$ & Duck & Live bird market \\
$\mathrm{A} / \mathrm{Ck} / \mathrm{Kr} / \mathrm{BC} 96 / 2010$ & $\mathrm{H} 9 \mathrm{~N} 2$ & Korean native chicken & Backyard flock \\
$\mathrm{A} / \mathrm{Ck} / \mathrm{Kr} / \mathrm{SNU} 11058 / 2011$ & $\mathrm{H} 9 \mathrm{~N} 2$ & Korean native chicken & Backyard flock \\
\hline
\end{tabular}

Ck: chicken, Dk: Duck, Kr: Korea 


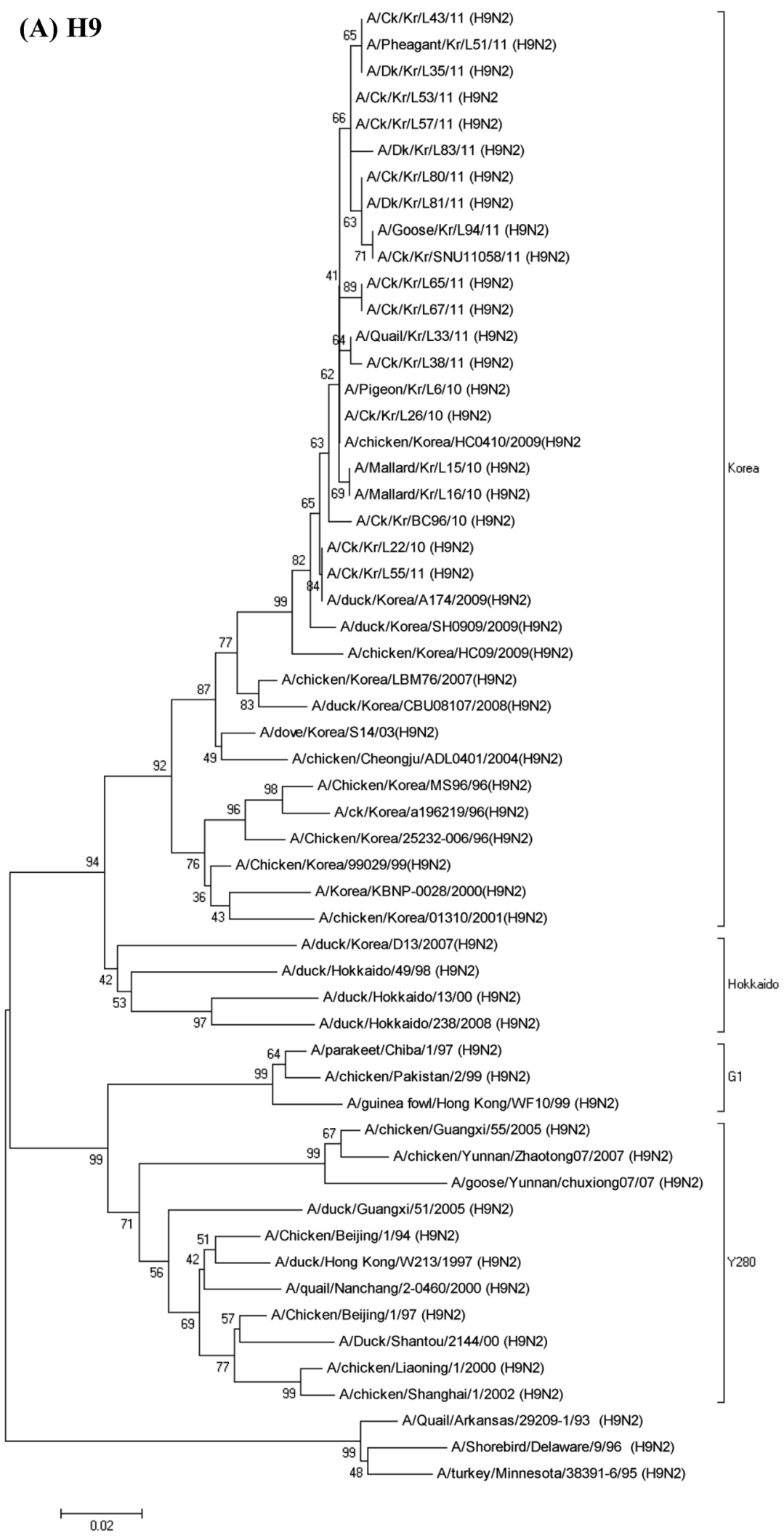

Fig. 1. Phylogenetic analysis of avian influenza viruses isolated from backyard chicken farms and live bird markets in Korea during 2010 2011. Phylogenetic analysis was performed using the MEGA version 5 software (neighbor-joining method and 1,000 bootstrapping repeats). (A) H9 gene, (B) N2 gene, (C) PB2 gene, (D) PB1 gene, (E) PA gene, (F) NP gene, (G) M gene, (H) NS gene, (I) H6 gene. 


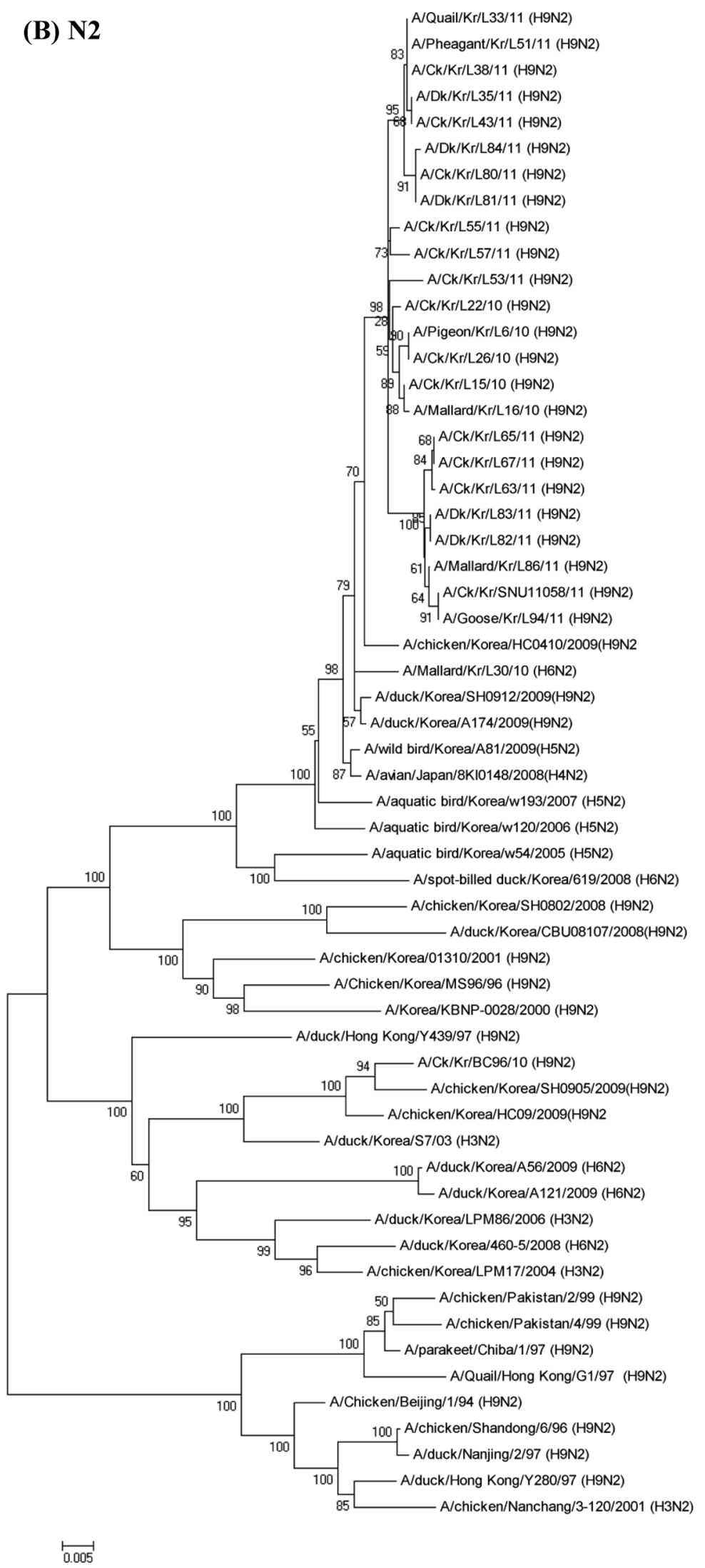

Fig. 1. continued 


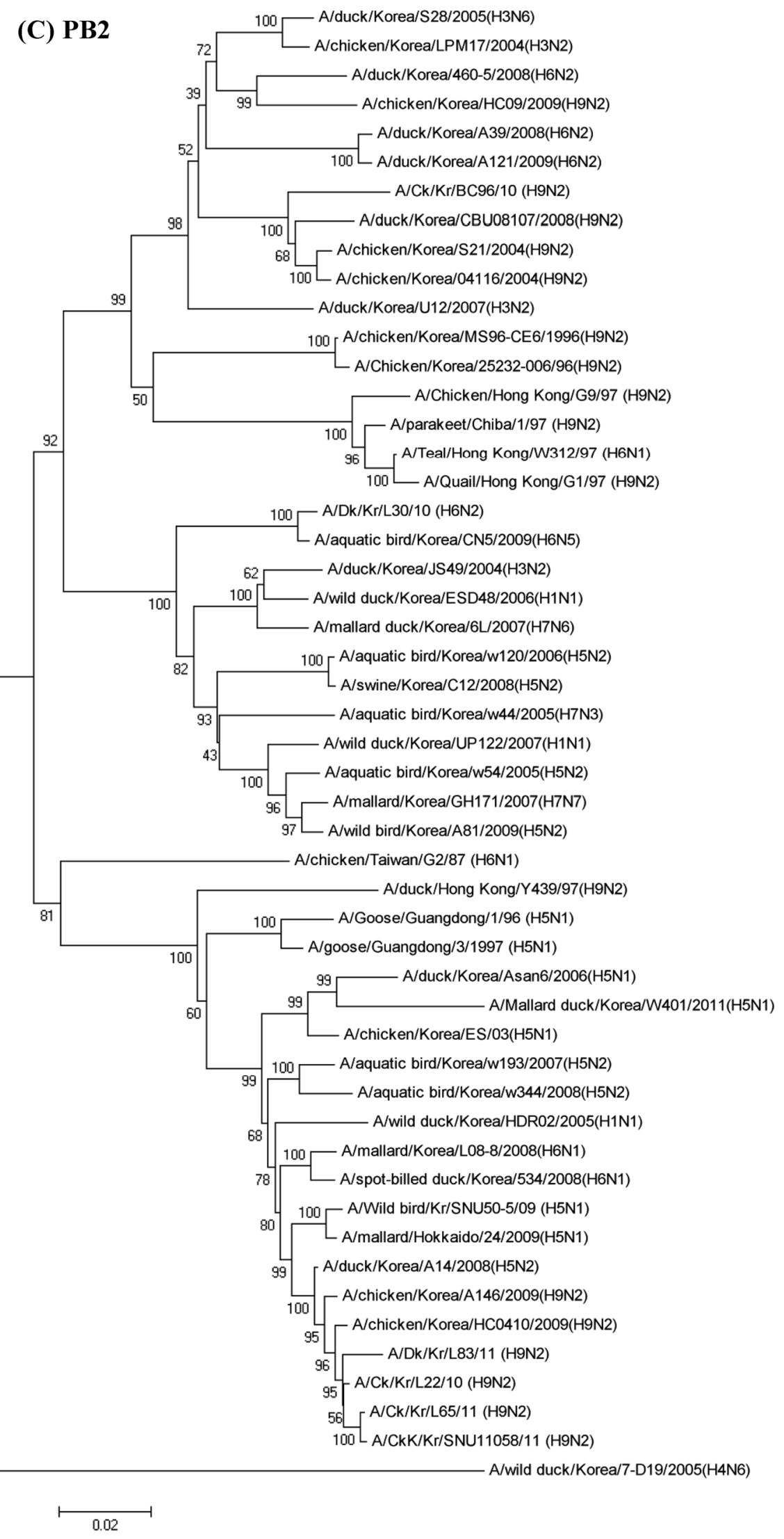

Fig. 1. continued 


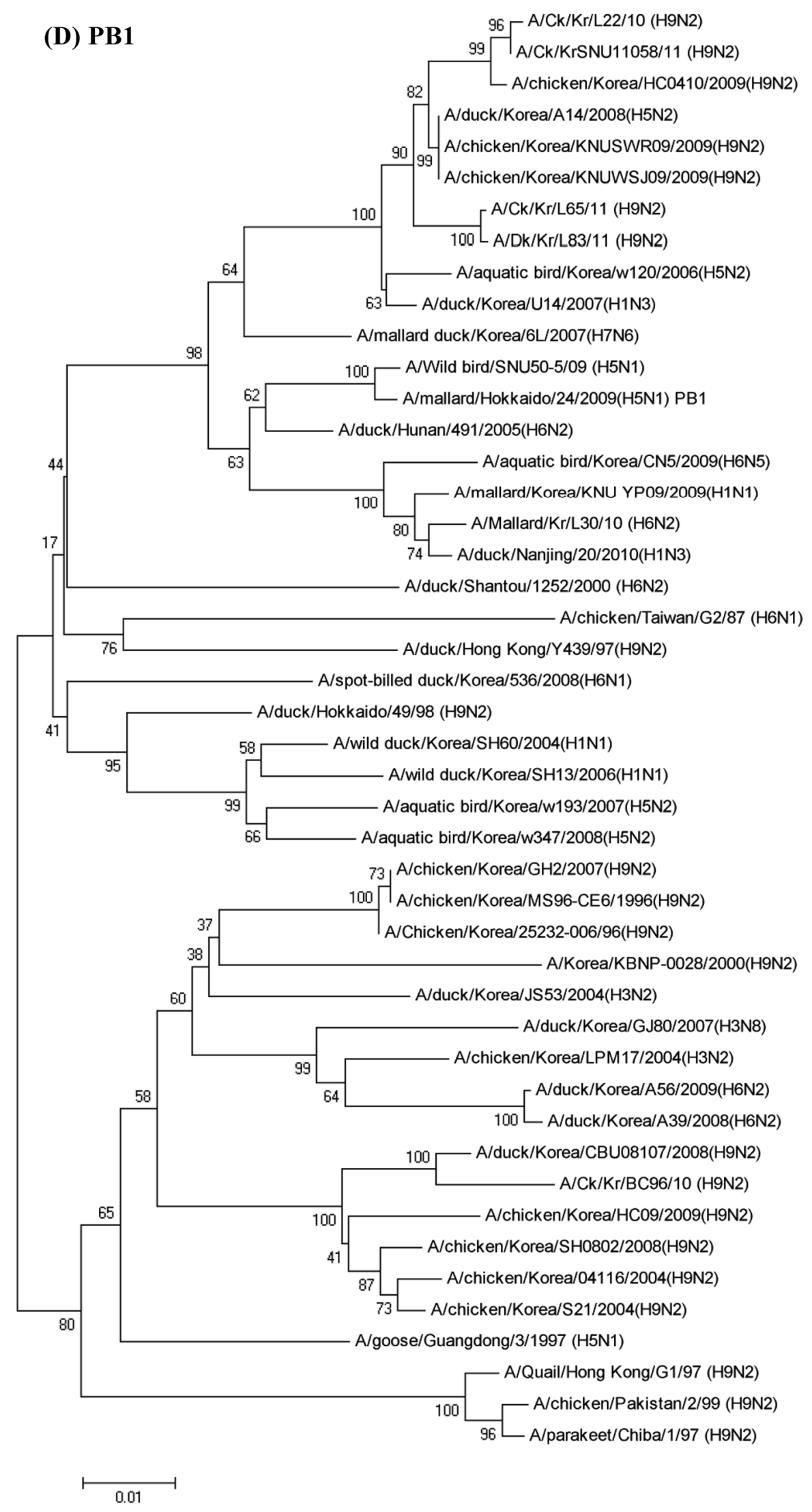

Fig. 1. continued 


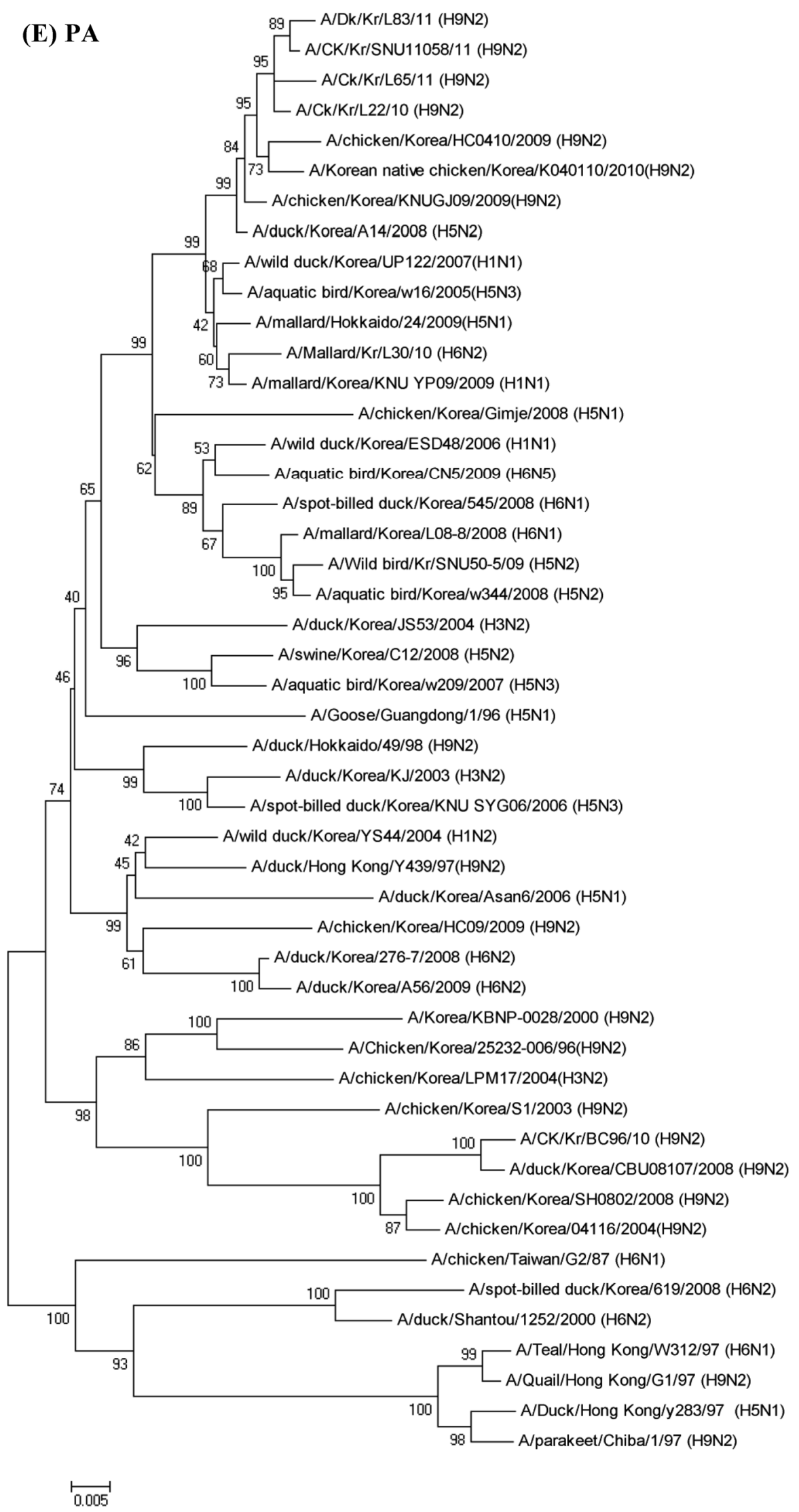

Fig. 1. continued 


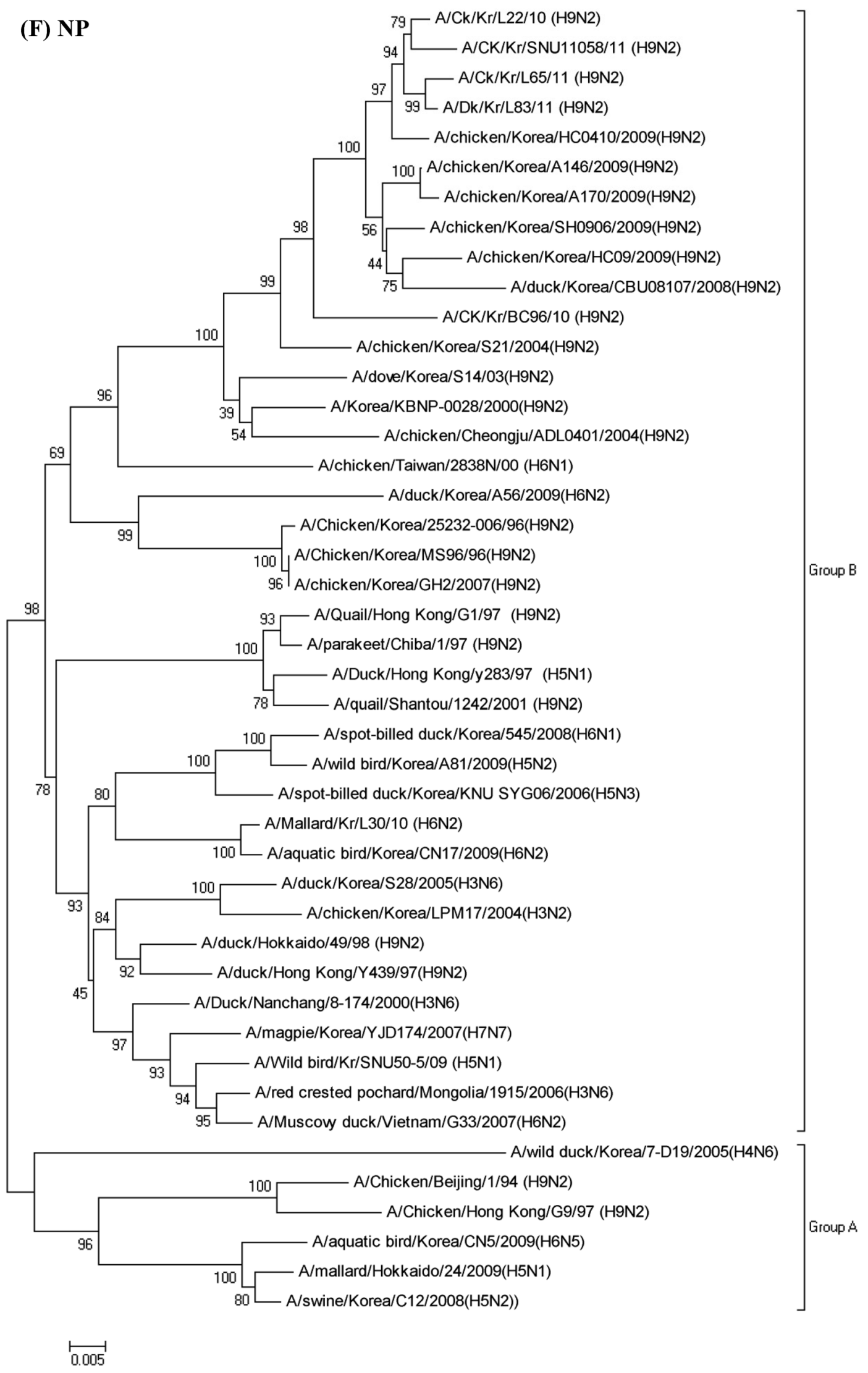

Fig. 1. continued 


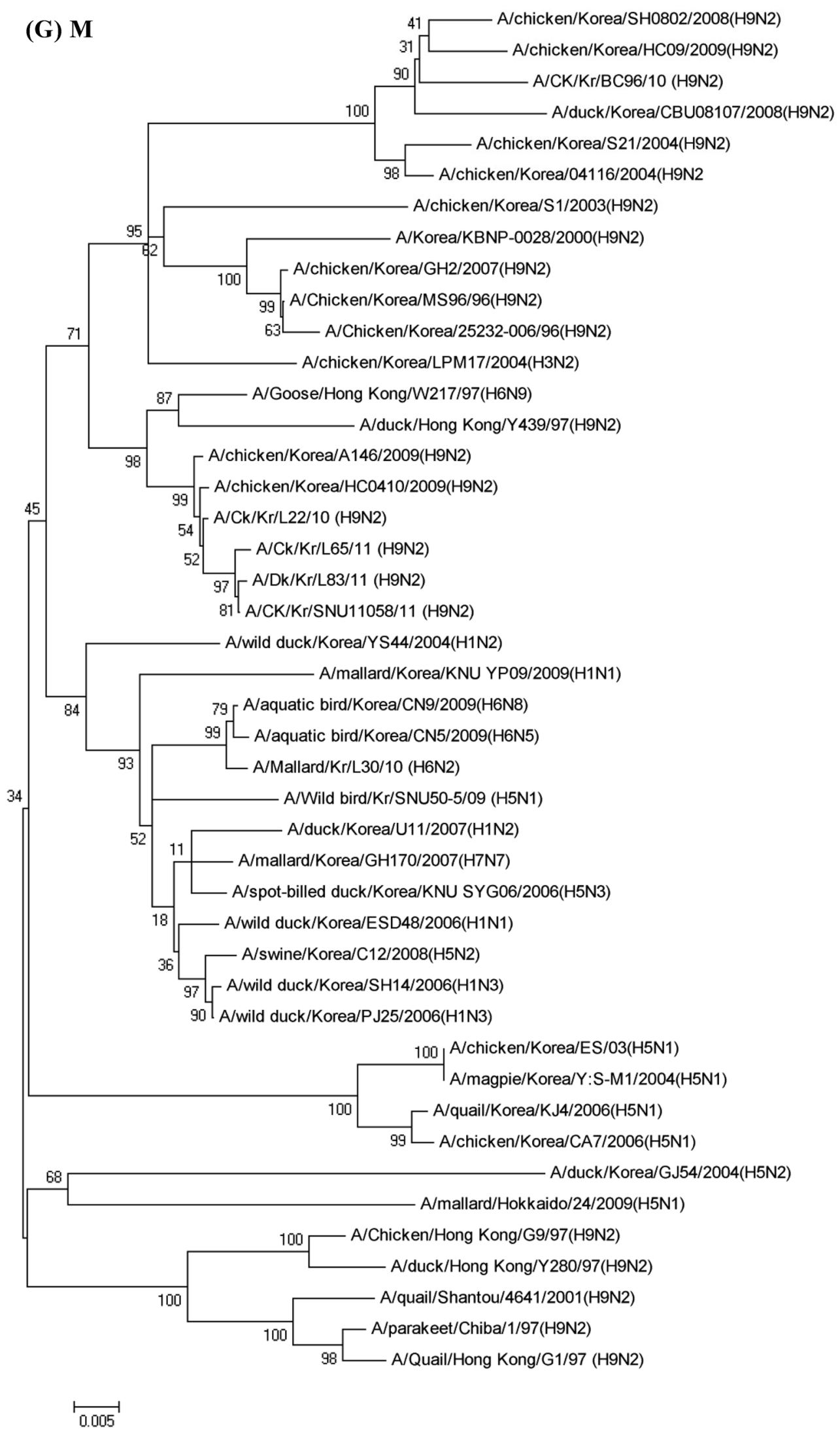

Fig. 1. continued 
(H) NS

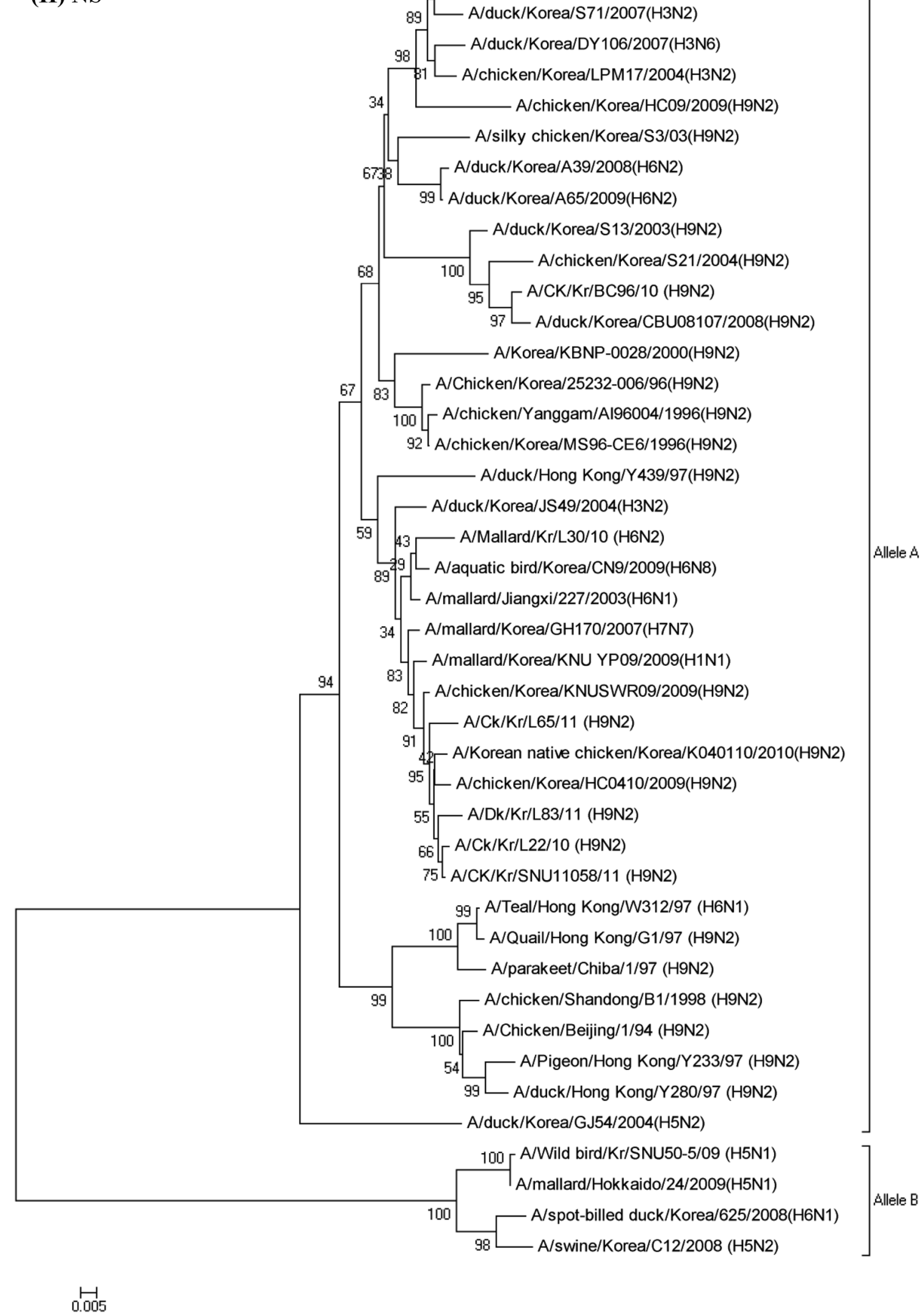

Fig. 1. continued 
(I) $\mathrm{H6}$

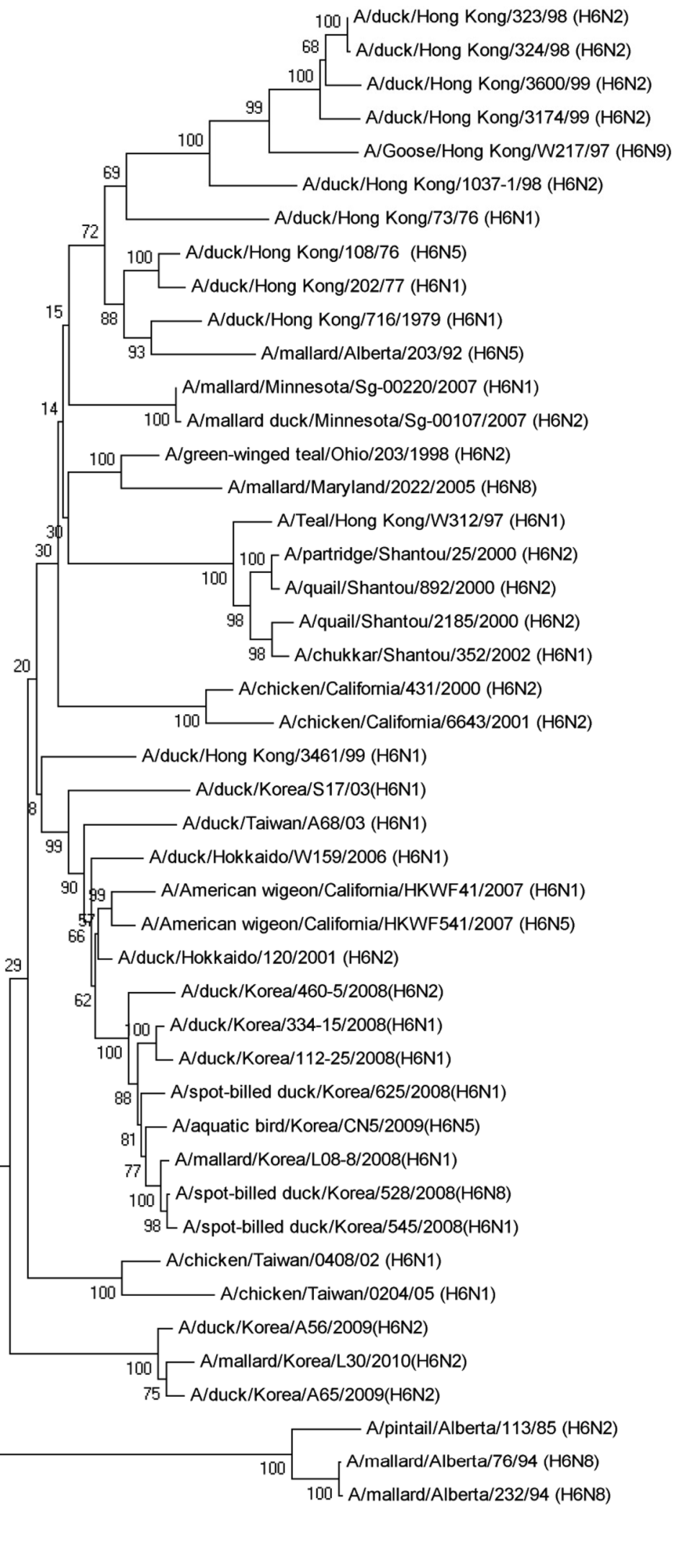

Fig. 1. continued 
Table 2. Replication of avian influenza virus isolates in chicken and mice*

\begin{tabular}{llll}
\hline \hline Virus & \multicolumn{2}{c}{ Chickens } & Mice \\
\cline { 2 - 3 } & Trachea & Cecal tonsil & Lung \\
\hline H9N2 & & & \\
A/Ck/Kr/L22/2010 & $5 / 5^{\dagger}\left(10^{4.3}\right)^{*}$ & $5 / 5\left(10^{5.3}\right)$ & $1 / 4\left(<10^{0.5}\right)$ \\
A/Ck/Kr/L65/2011 & $5 / 5\left(10^{3.5}\right)$ & $5 / 5\left(10^{5.1}\right)$ & $0 / 4\left(<10^{0.5}\right)$ \\
A/Dk/Kr/L83/2011 & $3 / 5\left(10^{4.5}\right)$ & $5 / 5\left(10^{4.9}\right)$ & $0 / 4\left(<10^{0.5}\right)$ \\
A/Ck/Kr/BC96/2010 & $2 / 5\left(<10^{0.5}\right)$ & $5 / 5\left(10^{4.7}\right)$ & $4 / 4\left(10^{2.1}\right)$ \\
A/Ck/Kr/SNU11058/2011 & $4 / 5\left(10^{1.1}\right)$ & $4 / 5\left(10^{5.7}\right)$ & $4 / 4\left(<10^{0.5}\right)$ \\
H6N2 & & & $0 / 4\left(<10^{0.5}\right)$ \\
A/Mallard/Kr/L30/2010 & $1 / 5\left(<10^{0.5}\right)$ & $2 / 5\left(<10^{0.5}\right)$ & \\
\hline
\end{tabular}

Ck: chicken, Dk: Duck, Kr: Korea. *All isolates were inoculated intranasally in 5-week-old SPF white leghorn layers and 4-week-old female $\mathrm{BALB} / \mathrm{c}$ mice. The titer of the inoculum was $10^{5.5} \sim 10^{6} \mathrm{EID}_{50} / 0.1 \mathrm{~mL}$. Number of the infected/number of the inoculated. ${ }^{*}$ Virus titer $\log _{10}$ $\mathrm{EID}_{50} / 0.1 \mathrm{~mL}$ at 5 d.p.i. in chickens and 3 d.p.i. in mice.

also divided into two groups. Most H9N2 isolates were related to recent AIVs from ducks and wild birds in Korea, whereas $\mathrm{A} / \mathrm{Ck} / \mathrm{Kr} / \mathrm{BC} 96 / 10$ was closely related to $\mathrm{A} / \mathrm{Ck} / \mathrm{Kr}$ / 04116/04-like AIVs (Figs. 1D and E).

The NP genes of all H9N2 isolates were clustered with the AIVs from domestic farms (Fig. 1F). The $\mathrm{M}$ genes of the H9N2 isolates were divided into two lineages. H9N2 isolates except for $\mathrm{A} / \mathrm{Ck} / \mathrm{Kr} / \mathrm{BC} 96 / 10$ were clustered with $\mathrm{A} / \mathrm{Dk} / \mathrm{HK} /$ Y439/97 [9]. Another isolate was related to the $\mathrm{A} / \mathrm{Ck} / \mathrm{Kr} /$ 04116/04-like lineage (Fig. 1G). The NS genes were clustered into Allele Group A and could be divided into two subgroups as with the $\mathrm{M}$ genes (Fig. 1H).

\section{Phylogenetic analysis of $\mathrm{H6N2}$ virus}

The HA gene of H6N2 clustered with the H6N2 AIVs circulating in domestic ducks in Korea (Fig. 1I). The NA gene showed high similarity to H9N2 isolates (Fig. 1B). The internal genes of the H6N2 isolate, when compared with other AIVs in Korea, showed that reassortment has been occurring among the AIVs circulating in migratory wild birds and domestic ducks in Korea (Figs. $1 \mathrm{C} \sim \mathrm{H})$.

\section{Antigenic determination}

A c-ELISA was performed to detect all subtypes of AIV antibodies. A total of 326 serum samples collected from zoo birds were tested by c-ELISA and 26 tested positive. All positive sera were determined to be $\mathrm{H} 5$ and $\mathrm{H} 7$ negative by $\mathrm{HI}$ testing. However, one serum sample was H9 positive even though the titer was low (data not shown). These results indicate that other subtypes of AIVs including $\mathrm{H} 9$ might infect zoo birds.

Out of 2243 serum samples from backyard poultry and 50 samples from LBMs, 356 and nine samples, respectively, tested positive for AIV antibodies by c-ELISA. Among them, 124 and 6 tested positive for H9 AIV by HI testing, respectively, even though all positive samples tested negative for H5 and/or H7 serotypes.

\section{Replication of avian influenza virus isolates in chicken and mice}

All of the H9N2 isolates inoculated into SPF chickens were detected in tracheas and cecal tonsils at 5 d.p.i.. Compared with the isolates from LBMs, the tracheal virus titers of the isolates from backyard flocks were lower, whereas the titers of the cecal tonsils were similar (Table 2). Although H6N2 AIV was detected in tracheal tissue and cecal tonsils, the titers were very low (Table 2).

Mice inoculated with H9N2 and H6N2 isolates showed no clinical signs or loss of weight. However, three different H9N2 AIVs were re-isolated from the lungs of mice inoculated with each $\mathrm{AIV}$; one $\mathrm{H} 9 \mathrm{~N} 2$ virus $(\mathrm{A} / \mathrm{Ck} / \mathrm{Kr} / \mathrm{BC} 96 / 10)$ showed replication in mice, where the titer was $2.1 \log _{10}$ $\mathrm{EID}_{50} / 0.1 \mathrm{~mL}$ at 3 d.p.i. (Table 2). Nevertheless, no antibody was detected from the mice at 14 d.p.i. by HI testing.

\section{Discussion}

AIVs have been isolated from domestic farms and LBMs in Korea, and the risk of spread and mutation of AIVs was reported in previous studies [14, 16, 18, 19]. However, AIV infections in zoo birds and backyard poultry flocks in Korea have not been systematically investigated even though a national surveillance program has been conducted since an outbreak of HPAI in 2003. In the present study, we surveyed the prevalence of AIV in zoos and backyard flocks and evaluated the risk of the spread and mutation of AIVs among these groups compared to AIVs from LBMs.

In zoos, various animals including avian species are raised and AIV infections in zoo animals have already been described [1, 2, 13, 20, 22]. One previous study investigated the transmission of H5N1 AIV in tigers in the zoo [25], suggesting that recent $\mathrm{H} 5 \mathrm{~N} 1 \mathrm{AIVs}$ have expanded their host ranges to infect human beings and other mammalian species as well as avian species, increasing the chance that spread of the virus could occur among wild birds and zoo animals. 
Thus, surveillance for AIVs in zoos was conducted in Bulgaria [5]. According to the results of the present study, no AIVs were isolated from zoo birds. However, 26 sera samples from poultry in the zoo tested positive for AIVs by cELISA and, among them, one was determined to have antibodies against the $\mathrm{H} 9$ subtype by $\mathrm{HI}$ testing. These results indicate that possible infection and circulation of AIVs might occur in zoo birds, which may increase the risk of the spread and mutation of AIVs among them. In some studies, vaccination against HPAIV in zoo birds was conducted and evaluated $[3,15,27]$.

The importance of AIV surveillance in LBMs has been strongly stressed and most results has confirmed that LBMs played a key role in the genetic reassortment and mutation of AIVs [16, 19]. In the present study, 26 H9N2 AIVs and one H6N2 AIV were isolated from backyard flocks and LBMs, but no AIVs were isolated from zoo birds. Phylogenetic analysis showed that all of the H9N2 isolates from LBMs were highly similar to $\mathrm{Ck} / \mathrm{Kr} / \mathrm{HC} 0410 / 09$ [21], which was isolated from a domestic chicken farm. It was also confirmed that H9N2 AIVs have continued to circulate and evolve between LBMs and domestic farms. Regarding the H6N2 isolate from an LBM, all genomic RNA segments except for the HA gene showed high similarity to AIVs circulating in migratory wild birds, and its genotype was different from H6N2 AIVs described previously in Korea [14]. These results indicate that genetic reassortment between AIVs has occurred among LBMs and wild birds.

Most backyard flocks were raised in open places with easy access by wild birds. Sometimes, various avian species were raised together in the same space. Phylogenetic analysis of two H9N2 isolates from backyard flocks revealed that the $\mathrm{AIV}$ isolate $\mathrm{A} / \mathrm{Ck} / \mathrm{Kr} / \mathrm{SNU} 11058 / 11$ showed high similarity to H9N2 AIVs from LBMs. In contrast, another isolate, A/ $\mathrm{Ck} / \mathrm{Kr} / \mathrm{BC} 96 / 10$, showed high similarity to $\mathrm{A} / \mathrm{Ck} / \mathrm{Kr} / 04116 /$ 04-like H9N2 AIVs circulating in domestic farms as described previously [19]. This suggests an epidemiologic relationship among circulating H9N2 AIVs in backyard flocks, domestic farms and LBMs. Moreover, some genomic RNA segments of the H9N2 isolates were related to migratory wild birds in Korea. Interestingly, A/Ck/Kr/BC96/10 showed different results in animals compared with A/Ck/Kr/LPM47/05 [19], although both AIVs were closely related to A/Ck/Kr/04116/04-like H9N2 AIVs. A/Ck/ Kr/BC96/10 replicated more readily in the lungs of mice than in the trachea of SPF chickens. In contrast, $\mathrm{A} / \mathrm{Ck} / \mathrm{Kr} / \mathrm{LPM} 47 / 05$ showed similar viral titers in the lungs of mice and the tracheas of SPF chickens [19]. The H6N2 AIV inoculated into SPF chickens was not readily replicated in the trachea or cecal tonsils and was detectable in only one or two chickens. These results suggest that the H6N2 isolate might have originated from wild birds and reassorted genetically among birds in LBMs.

In conclusion, we surveyed AIV infections in zoos, backyard farms and LBMs. Although AIVs were not isolated from zoo birds, the results of serological testing indicate that it is possible that AIV infections might occur in zoos. It was also confirmed that H9N2 AIVs continued to circulate and evolve among poultry, backyard flocks and birds in LBMs. Therefore, continuous surveillance, monitoring and investigation of these flocks should be conducted for the control of further epidemics.

\section{Acknowledgments}

This study was supported by a grant for 2010 to 2011 (ZAD15-2010-11-02) from the Animal, Plant \& Fisheries Quarantine and Inspection Agency (QIA), Ministry of Food, Agriculture, Forestry and Fisheries and BK21 for Veterinary Science and Research Institute of Veterinary Science, Seoul National University, Republic of Korea.

\section{References}

1. Alexander DJ. Isolation of influenza A viruses from birds in Great Britain during 1980 and 1981. Vet Rec 1982, 111, 319-321.

2. Amonsin A, Payungporn S, Theamboonlers A, Thanawongnuwech $R$, Suradhat $S$, Pariyothorn $N$, Tantilertcharoen $\mathrm{R}$, Damrongwantanapokin S, Buranathai $\mathrm{C}$, Chaisingh A, Songserm T, Poovorawan Y. Genetic characterization of $\mathrm{H} 5 \mathrm{~N} 1$ influenza A viruses isolated from zoo tigers in Thailand. Virology 2006, 344, 480-491.

3. Bertelsen MF, Klausen J, Holm E, Grøndahl C, Jørgensen PH. Serological response to vaccination against avian influenza in zoo-birds using an inactivated $\mathrm{H} 5 \mathrm{~N} 9$ vaccine. Vaccine 2007, 25, 4345-4349.

4. Bokma BH, Hall C, Siegfried LM, Weaver JT. Surveillance for avian influenza in the United States. Ann N Y Acad Sci 2006, 1081, 163-168.

5. Dimitrov KM, Manvell RJ, Goujgoulova GV. Status of wild birds in Bulgarian zoos with regard to orthomyxovirus and paramyxovirus type 1 infections. Avian Dis 2010, 54 (1 Suppl), 361-364.

6. Fereidouni SR, Starick E, Grund C, Globig A, Mettenleiter TC, Beer M, Harder T. Rapid molecular subtyping by reverse transcription polymerase chain reaction of the neuraminidase gene of avian influenza A viruses. Vet Microbiol 2009, 135, 253-260.

7. Garber L, Voelker L, Hill G, Rodriguez J. Description of live poultry markets in the United States and factors associated with repeated presence of $\mathrm{H} 5 / \mathrm{H} 7$ low-pathogenicity avian influenza virus. Avian Dis 2007, 51 (1 Suppl), 417-420.

8. Guan Y, Peiris M, Kong KF, Dyrting KC, Ellis TM, Sit T, Zhang LJ, Shortridge KF. H5N1 influenza viruses isolated from geese in Southeastern China: evidence for genetic reassortment and interspecies transmission to ducks. Virology 2002, 292, 16-23.

9. Guan Y, Shortridge KF, Krauss S, Chin PS, Dyrting KC, Ellis TM, Webster RG, Peiris M. H9N2 influenza viruses possessing H5N1-like internal genomes continue to circulate in poultry in southeastern China. J Virol 2000, 74, 9372-9380.

10. Guo YJ, Krauss S, Senne DA, Mo IP, Lo KS, Xiong XP, Norwood M, Shortridge KF, Webster RG, Guan Y. 
Characterization of the pathogenicity of members of the newly established H9N2 influenza virus lineages in Asia. Virology 2000, 267, 279-288.

11. Hall TA. BioEdit: a user-friendly biological sequence alignment editor and analysis program for Windows 95/98/NT. Nucl Acids Symp Ser 1999, 41, 95-98.

12. Hoffmann E, Stech J, Guan Y, Webster RG, Perez DR. Universal primer set for the full-length amplification of all influenza A viruses. Arch Virol 2001, 146, 2275-2289.

13. Keawcharoen J, Oraveerakul K, Kuiken T, Fouchier RA, Amonsin A, Payungporn S, Noppornpanth $\mathrm{S}$, Wattanodorn S, Theambooniers A, Tantilertcharoen $R$, Pattanarangsan $\mathrm{R}$, Arya $\mathrm{N}$, Ratanakorn $\mathrm{P}$, Osterhaus DM, Poovorawan Y. Avian influenza H5N1 in tigers and leopards. Emerg Infect Dis 2004, 10, 2189-2191.

14. Kim HR, Lee YJ, Lee KK, Oem JK, Kim SH, Lee MH, Lee OS, Park CK. Genetic relatedness of H6 subtype avian influenza viruses isolated from wild birds and domestic ducks in Korea and their pathogenicity in animals. J Gen Virol 2010, 91 (Pt 1), 208-219.

15. Lécu A, De Langhe C, Petit T, Bernard F, Swam $\mathbf{H}$. Serologic response and safety to vaccination against avian influenza using inactivated $\mathrm{H} 5 \mathrm{~N} 2$ vaccine in zoo birds. J Zoo Wildl Med 2009, 40, 731-743.

16. Lee HJ, Kwon JS, Lee DH, Lee YN, Youn HN, Lee YJ, Kim MC, Jeong OM, Kang HM, Kwon JH, Lee JB, Park SY, Choi IS, Song CS. Continuing evolution and interspecies transmission of influenza viruses in live bird markets in Korea. Avian Dis 2010, 54 (1 Suppl), 738-748.

17. Lee MS, Chang PC, Shien JH, Cheng MC, Shieh HK. Identification and subtyping of avian influenza viruses by reverse transcription-PCR. J Virol Methods 2001, 97, 13-22.

18. Lee YJ, Shin JY, Song MS, Lee YM, Choi JG, Lee EK, Jeong OM, Sung HW, Kim JH, Kwon YK, Kwon JH, Kim CJ, Webby RJ, Webster RG, Choi YK. Continuing evolution of $\mathrm{H} 9$ influenza viruses in Korean poultry. Virology 2007, 359, 313-323.

19. Moon HJ, Song MS, Cruz DJ, Park KJ, Pascua PN, Lee JH, Baek YH, Choi DH, Choi YK, Kim CJ. Active reassortment of $\mathrm{H} 9$ influenza viruses between wild birds and live-poultry markets in Korea. Arch Virol 2010, 155, 229-241.

20. Mushtaq MH, Juan H, Jiang P, Li Y, Li T, Du Y, Mukhtar MM. Complete genome analysis of a highly pathogenic $\mathrm{H} 5 \mathrm{~N} 1$ influenza A virus isolated from a tiger in China. Arch Virol 2008, 153, 1569-1574.

21. Park KJ, Kwon HI, Song MS, Pascua PN, Baek YH, Lee JH, Jang HL, Lim JY, Mo IP, Moon HJ, Kim CJ, Choi YK. Rapid evolution of low-pathogenic H9N2 avian influenza viruses following poultry vaccination programmes. J Gen Virol 2011, 92 (Pt 1), 36-50.

22. Starick E, Beer M, Hoffmann B, Staubach C, Werner O, Globig A, Strebelow G, Grund C, Durban M, Conraths FJ, Mettenleiter T, Harder T. Phylogenetic analyses of highly pathogenic avian influenza virus isolates from Germany in 2006 and 2007 suggest at least three separate introductions of H5N1 virus. Vet Microbiol 2008, 128, 243252.

23. Tamura K, Peterson D, Peterson N, Stecher G, Nei M, Kumar S. MEGA5: molecular evolutionary genetics analysis using maximum likelihood, evolutionary distance, and maximum parsimony methods. Mol Biol Evol 2011, 28, 2731-2739.

24. Terregino C, De Nardi R, Guberti V, Scremin M, Raffini E, Martin AM, Cattoli G, Bonfanti L, Capua I. Active surveillance for avian influenza viruses in wild birds and backyard flocks in Northern Italy during 2004 to 2006. Avian Pathol 2007, 36, 337-344.

25. Thanawongnuwech R, Amonsin A, Tantilertcharoen R, Damrongwatanapokin S, Theamboonlers A, Payungporn S, Nanthapornphiphat K, Ratanamungklanon S, Tunak E, Songserm T, Vivatthanavanich V, Lekdumrongsak T, Kesdangsakonwut S, Tunhikorn S, Poovorawan Y. Probable tiger-to-tiger transmission of avian influenza H5N1. Emerg Infect Dis 2005, 11, 699-701.

26. Trock SC, Gaeta M, Gonzalez A, Pederson JC, Senne DA. Evaluation of routine depopulation, cleaning, and disinfection procedures in the live bird markets, New York. Avian Dis 2008, 52, 160-162.

27. Vergara-Alert J, Fernández-Bellon $\mathbf{H}$, Busquets $\mathbf{N}$, Alcántara G, Delclaux M, Pizarro B, Sánchez C, Sánchez A, Majó N, Darji A. Comprehensive serological analysis of two successive heterologous vaccines against H5N1 avian influenza virus in exotic birds in zoos. Clin Vaccine Immunol 2011, 18, 697-706.

28. Webster RG, Peiris M, Chen H, Guan Y. H5N1 outbreaks and enzootic influenza. Emerg Infect Dis 2006, 12, 3-8. 